Henry, K. M. \& Kon, S. K. (1957). Brit. F. Nutr. 11, 305.

Henry, K. M., Kon, S. K., Lea, C. H. \& White, J. C. D. (I948). F. Dairy Res. 15, 292.

Henry, K. M., Kon, S. K. \& Rowland, S. J. (I946). F. Dairy Res. I4, 403.

Hodson, A. Z. (1952). Food Res. 17, 68.

Hodson, A. Z. \& Krueger, G. M. (I947). Arch. Biochem. 12, 5 I.

Hodson, A. Z. \& Miller, C. B. (r957). Food Tech., Champaign, 1x, 89.

Jones, D. B., Divine, J. P. \& Gersdorff, C. E. F. (I942). Cereal Chem. 19, 819.

Koch, B. A. \& Meyer, J. N. (1957). F. Nutr. 61, 343 .

Lan, T. H. (1936). Chin. F. Physiol. 1o, 637.

Larson, P. S. \& Chaikoff, I. L. (1937). F. Nutr. 13, 287.

Leverton, R. M. \& Gram, M. R. (1949). F. Nutr. 39, 57.

Leverton, R. M., Gram, M. R. \& Chaloupka, M. (195I). 7. Nutr. 44, 537.

Macrae, T. F., Henry, K. M. \& Kon, S. K. (1943). Biochem. F. 37, 225.

Mitchell, H. H. (1923-4). F. biol. Chem. 58, 873 .

Mitchell, H. H. (1950). In Protein and Amino Acid Requirements of Mammals, p. x. [A. A. Albanese, editor.] New York: Academic Press Inc.

Mitchell, H. H. \& Beadles, J. R. (1949). F. Nutr. 39, 463.

Mitchell, H. H. \& Carman, G. G. (1926). F. biol. Chem. 68, 183.

Mitchell, H. H., Hamilton, T. S. \& Beadles, J. R. (1949). F. Nutr. 39, 413.

Morgan, A. F. \& Kern, G. E. (1934). F. Nutr. 7, 367.

Munro, H. N. (1949). F. Nutr. 39, 375.

Osborne, T. B., Mendel, L. B. \& Ferry, E. L. (1919). F. biol. Chem. 37, 223.

Oser, B. L. (195 L). F. Amer. diet. Ass. 27, 396.

Pretorius, P. J., Hansen, J. D. L., Davel, J. G. A. \& Brock, J. F. (I956). S. Afr. med. F. 30, 447.

Ramachandran, M. \& Phansalkar, S. V. (1956). Indian F. med. Res. 44, 501.

Robscheit-Robbins, F. S. \& Whipple, G. H. (1949). F. exp. Med. 89, 359.

Rose, W. C. (1938). Physiol. Rev. 18, I09.

Rose, W. C. (1949). Fed. Proc. 8, 546.

Sheffner, A. L., Eckfeldt, G. A. \& Spector, H. (1956). F. Nutr. 60, 105 .

Schulz, J. A. \& Thomas, B. H. (1949). Cereal Chem. 26, 60.

Swaminathan, M. (I937). Indian F. med. Res. 25, 399.

Swaminathan, M. (1938). Indian $\%$. med. Res. 26, I I 3 .

Thomas, K. (1909). Arch. Anat. Physiol., Lpz., Physiol. Abt. p. 2 19.

Wan, S. \& Lee, W. J. (1931). Chin. F. Physiol. 5, 163.

Whipple, G. H. \& Robscheit-Robbins, F. S. (1951). F. exp. Med. 94, 223.

\title{
Biological methods of evaluating protein quality
}

By A. E. Bender, Research Department, Bovril Ltd, ${ }_{4} 8$ Old Street, London, E.C.I

Proteins are unique among the foodstuffs in that the same name is given to a large number of heterogeneous substances. It is as if one were considering the nutritional properties of the vitamins as a group, without specifying which vitamin is under consideration. Although the terms fats and carbohydrates each cover a group of substances the properties of all the members of those groups are similar; moreover carbohydrates are subdivided into more specific groupings. With proteins, however, vast numbers of substances of differing composition and differing nutritive value are all covered by the one name.

That the different nutritional values of proteins are not generally taken into account is indicated by the wide acceptance of ' $\mathrm{N} \times 6.25$ ' as an adequate description of protein foods despite the fact that proteins can vary between 0 and $100 \%$ availability for physiological purposes. 
It is not possible at present to determine the availability without recourse to biological measurement. The difficulty of maintaining a colony of experimental animals and the labour and expense of carrying out biological assays has forced many a chemist to remain satisfied with ' $\mathrm{N} \times 6 \cdot 25$ '. The recent introduction of abbreviated biological assays, in particular of microbiological techniques, should now allow biological measurements to be carried out in what have been, hitherto, purely chemical laboratories.

\section{The problem}

The question to be answered is "what is the "value" of the protein under investigation to man or domestic animal?' The animal can use protein to replace metabolic losses, for the construction of new tissue as in growth, for reproduction, for lactation, or, looked at from another point of view, for meat, wool, egg, or milk production. It is possible to measure these effects directly on the particular animal or man, but the technical difficulties are very great. Consequently a number of experimental methods have been developed to determine an index of the 'value' of a protein. Apart from the microbiological tests, the rat is the most commonly used animal, and to a far lesser extent the dog, mouse, chicken and pig.

It is important to realize the conventional nature of these tests and to appreciate the significance of the results. The proteins are assayed under specified conditions, under which protein is the limiting factor in the diet, and the results obtained may not be applicable under other conditions, e.g. with change of level of protein fed, composition of the diet, age and species of experimental animal.

Under the particular conditions of the test, the result is merely an index of the value of the protein for the various functions listed above. The information obtained is nevertheless often of wide application.

\section{Methods of assay}

The methods can be grouped as follows: (I) screening tests, (2) quantitative measurements, (3) indirect methods, and (4) practical feeding tests. The method of choice must depend on the information required. The terms used are defined in Table I.

\section{Screening tests}

Very often far too much effort is devoted to obtaining detailed figures, which, in any event, have only an apparent precision, when all that is wanted is an approximate grading or comparative results. A simple test, in which a number of samples can be examined at the same time, is then the prime requirement. The 'screening' tests fulfil this requirement and, in addition, often yield a great deal of more fundamental information.

Protein efficiency ratio. The simplest and most obvious measure of nutritive value is the growth rate of young animals fed on the foodstuff in question. For proteins this crude procedure was placed on a quantitative basis in the early days by Osborne 
\& Mendel (I917), who related the weight increase to the amount of protein eaten and so defined protein efficiency ratio (P.E.R.). They showed that P.E.R. varied with the level of protein in the diet and recommended that each protein should be assayed at its optimum level. As this procedure would necessitate preliminary experiments to determine the optimum it has not been followed by later workers who have almost universally adopted the convention of giving the protein at the $10 \%$ level.

Net protein retention. The drawbacks of P.E.R. have been repeatedly pointed out (Mitchell \& Carman, 1926; Mitchell, 1944; Bender, 1956) and include (a) that the assumption that weight increase is an index of protein synthesis is not necessarily valid, (b) that results vary with the level of protein in the diet, (c) that results vary with food intake, and (d) that proteins that do not produce growth cannot be evaluated. A modification of the method which obviates these last two criticisms has recently been introduced and the value it measures called net protein retention (Bender \& Doell, 1957). A control group of litter-mate rats is fed on a non-protein diet during the experiment, and the final weight of this group, instead of the initial weight of the test group, is subtracted from the final weight of the experimental group.

Rat-repletion method. In the rat-repletion method (Cannon, 1948) the weight regained by protein-depleted adult rats given the test protein serves as a measure of protein quality instead of the weight gain of growing rats. The advantages of the method are that recovery of weight parallels changes in carcass protein and that the same rats can be used for several determinations.

Microbiological assay. An entirely different method is based on the finding that the protozoan, Tetrahymena pyriformis, has amino-acid requirements similar to those of the higher animals. Moreover, the organism is able to digest whole protein.

The method was introduced by Rockland \& Dunn (1949), who used acid production over $4 \mathrm{I}$ days as an index. It was developed into a more precise method by Fernell \& Rosen (1956), using growth in relation to ammonia production as an index of protein value over a 4 -day growth period. This is the most rapid of the biological methods of protein evaluation (apart from the single-dose rat method of Silber \& Porter (1950) designed for protein hydrolysates) and is consequently of special value where an early result is required. In addition to the speed of this method the fact that very large numbers of proteins can be tested simultaneously makes it extremely useful as a screening test or for comparing methods of processing. The various drawbacks of all microbiological methods and the far cry from protozoa to mammals are not of great importance if one recognizes the test as an indirect index of protein value and as a means of comparison. Nevertheless, the method may be of even greater value in view of the close parallelism that Rosen \& Fernell (1956) found between the Tetrahymena and the rat assays.

A similar but less successful approach was that of Halevy \& Grossowicz (r953) using Streptococcus faecalis and of Horn, Blum, Womack \& Gersdorff (1952) using Leuconostoc mesenteroides on enzymic protein hydrolysates. 


\section{Quantitative measurements}

The measurement of nitrogen balance yields certain fundamental information, and assay methods based on it are capable of reasonable precision. The original method was that of Thomas (I909) and Mitchell $(1923-4 a, b)$ with subsequent modifications aimed at brevity or greater accuracy.

Thomas-Mitchell method. This method measures the percentage of the absorbed $\mathrm{N}$ retained in the body, which is defined as the biological value, from the difference between intake and excretion. The practical measurement has to take account of the normal $\mathrm{N}$ turnover of the body and entails a rather lengthy procedure. It is not sufficient to subtract faecal $\mathrm{N}$ from dietary $\mathrm{N}$ in order to determine the proportion absorbed, as there is always a faecal $\mathrm{N}$ excretion even on a non-protein diet-the metabolic N. Similarly, to measure the retention, the urine $\mathrm{N}$ has to be corrected for endogenous losses. For this reason the definition of biological value comprises the rather complicated equation shown in Table $I$.

Table I. Definitions

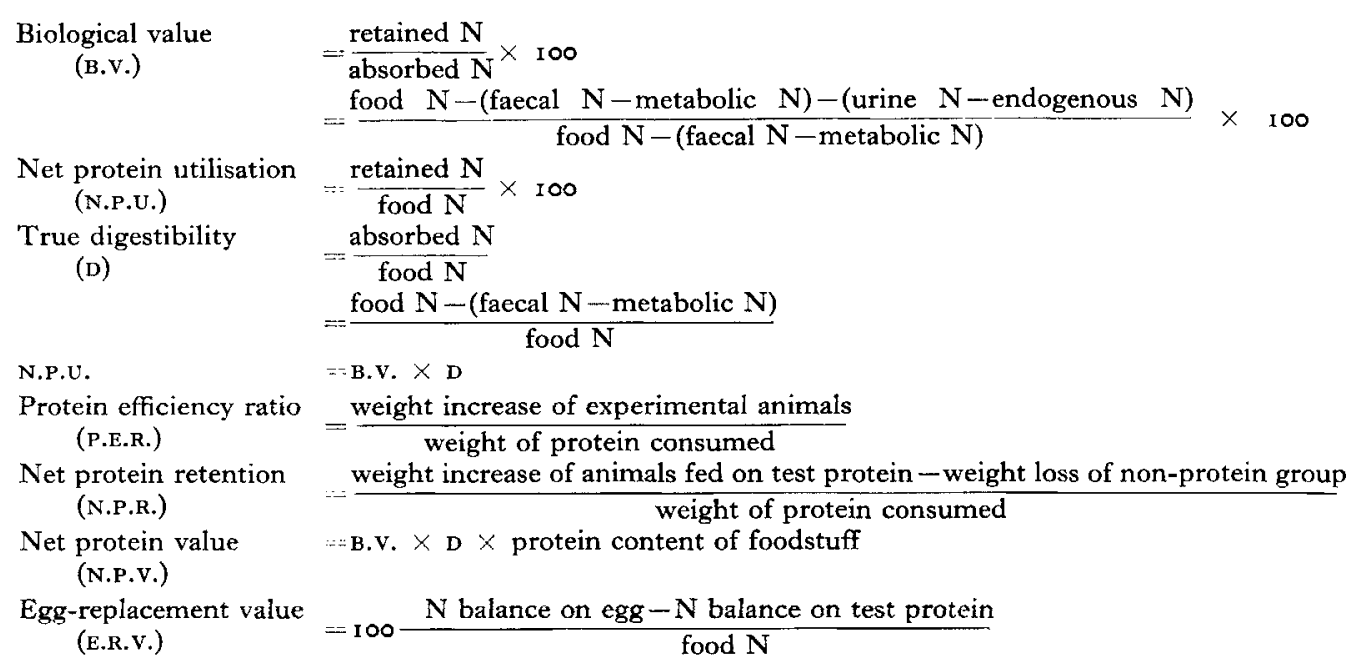

It is regrettable that the specific term 'biological value' is often used loosely when the general term 'nutritional value' is meant. The errors that can arise from the misuse of these technical terms are illustrated by the inaccurate claims for the effects of fortifying bread protein with lysine (Bender, I957).

Nitrogen-balance index. The N-balance index method of Allison \& Anderson (I945) was introduced partly to obviate errors in measuring endogenous $\mathrm{N}$ excretion. Different levels of protein are given and the $\mathrm{N}$ balance is plotted against the $\mathrm{N}$ intake. In the region of small positive balance and of negative balance the relationship approximates to a straight line, the slope of which is defined as $\mathrm{N}$-balance index, and is closely related to biological value. This method is readily applicable to human beings (Hoffman \& McNeil, I949) as it is only necessary to measure $\mathrm{N}$ balance at two levels of intake. 
Carcass-nitrogen method. A more recently introduced abbreviation is that of carcass-nitrogen determination (Bender \& Miller, 1953; Miller \& Bender, 1955). The percentage retention is measured from carcass analysis instead of from the difference between intake and output. As these authors found a relation between body water and body protein, a simple water determination is sufficient from which to calculate the carcass $\mathrm{N}$. The method has the great advantage of brevity and appears to give answers similar to those obtained from the full Mitchell procedure. Nitrogen needs to be determined only in the food whereas a large number of determinations of faecal and urinary $\mathrm{N}$ is required in the Mitchell method.

Egg-replacement value. Murlin, Nasset \& Marsh (1938) gave this name to an earlier method in which nitrogen balance on a test diet was compared with that on a standard protein diet. It has been used a great deal in human experiments and the results obtained with many, but not all, proteins agree with their biological value.

Growth and nitrogen balance. Shukers \& McCollum (quoted by McCollum \& Simmonds, 1929) introduced a method which included both growth and $\mathrm{N}$ balance. They determined the initial $\mathrm{N}$ content of the carcasses of one experimental group of rats and fed two other groups on the test protein for 28 and 56 days. At the end of the experimental period the animals were killed and their carcass protein was determined. The result was calculated as the gain in body protein/g protein eaten and is thus similar to P.E.R.

\section{Relation between growth methods and $\mathrm{N}$-balance methods}

It is usual to regard growth methods as being of a different type from $\mathrm{N}$-balance methods. In this paper the segregation is into applications rather than procedures and, as hitherto carried out, growth methods are useful mainly for screening tests and nitrogen-balance methods for more precise measurements. In point of fact there is no real distinction between growth and balance methods. $\mathrm{N}$ balance measures the protein tissue laid down in the experimental animal. This figure is clearly related to weight increase. Bender \& Doell (1957) observed empirically under specific conditions that the difference between the weights of the protein-fed and proteindeprived rats, divided by the protein intake (that is N.P.R.) and multiplied by a factor of 16 (the percentage of protein in the carcass), yielded the same numerical value as net protein utilization (see Table $\mathrm{r}$ ) calculated from carcass $\mathrm{N}$. This value was called protein retention efficiency.

\section{Indirect methods}

In an attempt to short-circuit the rather lengthy procedures involved in estimations of biological value several indirect methods have been suggested.

Measurement of creatinine. Murlin, Szymanski \& Nasset (1948) showed a straightline relationship between в.v. and urinary creatinine of animals fed on a range of proteins. They suggested that B.v. could be calculated from the percentage of urinary creatinine if the test protein was fed at a low level with the animal in negative $\mathrm{N}$ balance.

Short-term $N$-retention test. Silber \& Porter (1950) modified the N-balance technique into a I-day test. After I week of protein depletion rats were given the test 
protein in a single meal. The total amount of $\alpha$-amino-acids excreted in the urine was measured and the retention calculated from it. The method is of value in testing protein hydrolysates intended for clinical use.

Measurement of restitution. On a protein-free diet $\mathrm{N}$ stores are rapidly depleted, and the urine $\mathrm{N}$ falls. 'Two days' protein feeding regenerates the stores in the rat and on subsequent depletion this $\mathrm{N}$ is excreted. The $\mathrm{N}$ excretion after regeneration depends upon the degree of regeneration and hence upon the nutritive value of the protein. Vardi \& Tatar (I 954) measured this 'restitution N' after a cycle of depletionrepletion-depletion in the rat and suggested a biological assay based on its use. There are not enough data available to assess the usefulness of the method.

Measures of single response. Several methods involving the examination of single responses to protein feeding have been developed. For example, plasma proteins are reduced by underfeeding or by repeated bleeding (Whipple, I948) or animals are rendered anaemic with phenylhydrazine (Moorjani \& Subrahmanyan, 1950) and the rate of regeneration of plasma protein or haemoglobin after feeding on proteins is used as an index of protein quality. Similarly regeneration of liver protein (Campbell \& Kosterlitz, r948) and specific liver-enzyme regeneration have been measured. All these methods, however, measure only one effect of the test protein, although some have been developed as an index of its general value. A considerable drawback as a general assay is that some proteins stimulate the regeneration of one tissue more than another, e.g. casein stimulates regeneration of serum albumin and globulin, whereas bovine serum protein and lactalbumin cause regeneration of only serum albumin (Seeley, I945), and meat favours regeneration of haemoglobin, whereas egg favours that of plasma protein (Robscheit-Robbins \& Whipple, 1949). Thus these techniques can give only specialized information and are rather removed from the usual considerations of nutritive value. Chow, Alper \& De Biase (1948) tabulated the results for seven proteins assayed by nitrogen-balance index, P.E.R., rat repletion, liver regeneration, total plasma protein, and albumin and globulin regeneration. The different methods placed the proteins in different orders of value.

\section{Practical feeding tests}

Gross protein value. The various methods outlined above provide an index of nutritive value which the practical man relates to human nutrition or to food production from domestic animals. What is often required, however, is an experimental version of a field test. It is provided by the gross protein value determination on chicks (Heiman, Carver \& Cook, r939). Here the diet is based on the normal practical diet of cereal, given at $8 \%$ protein level, supplemented with $3 \%$ test protein. The diet thus simulates farming conditions where a knowledge of the nutritive value of the combination of dietary proteins is required rather than the more academic information on the biological value of a protein concentrate alone. The measure is the extra growth of the chicks (beyond that of those fed on the cereal ration alone) per $g$ of the supplementary protein eaten over a 2 -week period. 
All measures of protein quality are a function of the limiting amino-acid, because the usefulness of a protein is limited by the amino-acid in shortest supply. The tests do not, therefore, yield any information about the other amino-acids, i.e. the potential value of the protein if given in combination with other proteins. This point needs emphasis because so often its B.V. or P.E.R. is taken as a complete description of a protein. It is possible to find two proteins with the same B.v. but with different amounts of the non-limiting essential amino-acids.

\section{REFERENCES}

Allison, J. B. \& Anderson, J. A. (1945). 7. Nutr. 29, 4 I 3.

Bender, A. E. (1956). Brit. $\mathcal{F}$. Nutr. 10, 135.

Bender, A. E. (1957). Proc, Nutr. Soc. 16, xviii.

Bender, A. E. \& Doell, B. H. (1957). Brit. F. Nutr. II, 140.

Bender, A. E. \& Miller, D. S. (1953). Biochem. Y. 53, vii.

Campbell, R. M. \& Kosterlitz, H. W. (1948). F. Physiol. ro7, 383 .

Cannon, P. R. (1948). Protein and Amino Acid Deficiencies. Springfield, Ill.: C. C. Thomas.

Chow, B. F., Alper, C. \& De Biase, S. (r948). F. Nutr. 36, 785 .

Fernell, W. R. \& Rosen, G. D. (1956). Brit. Y. Nutr. 10, 143.

Halevy, S. \& Grossowicz, N. (1953). Proc. Soc. exp. Biol., N.Y., 82, 567.

Heiman, V., Carver, J. S. \& Cook, J. W. (1939). Poult. Sci. r8, 464.

Hoffman, W. S. \& McNeil, G. C. (1949). F. Nutr. 38, 33 I.

Horn, M. J., Blum, A. E., Womack, M. \& Gersdorff, C. E. F. (1952). F. Nutr. 48, 23 I.

McCollum, E. V. \& Simmonds, N. (1929). The Newer Knowledge of Nutrition, 4th ed., p. 82 . New York: The Macmillan Company.

Miller, D. S. \& Bender, A. E. (1955). Brit. F. Nutr. 9, $3^{82}$.

Mitchell, H. H. (1923-4a). F. biol. Chem. 58,873.

Mitchell, H. H. $(1923-4 b)$. F. biol. Chem. 58, 905 .

Mitchell, H. H. (1944). Inḋustr. Engng Chem. 16, 696.

Mitchell, H. H. \& Carman, C. G. (1926). Amer. F. Physiol. 76, 398.

Moorjani, M. N. \& Subrahmanyan, V. (1950). Indian 7. med. Res. 38, 145.

Murlin, J. R., Nasset, E. S. \& Marsh, M. E. (1938), F. Nutr. 16, 249.

Murlin, J. R., Szymanski, T. A. \& Nasset, E. C. (I 948). F. Nutr. 36, I 71.

Osborne, T. B. \& Mendel, L. B. (r9iz). F. biol. Chem. 32, 369.

Robscheit-Robbins, F. S. \& Whipple, G. H. (1949). F. exp. Med. 89, 339.

Rockland, L. B. \& Dunn, M. S. (1949). Food Tech. 3, 289.

Rosen, G. D. \& Fernell, W. R. (1956). Brit. F. Nutr. 10, $5_{5} 6$.

Seeley, R. D. (1945). Amer. F. Physiol. 144, 369.

Silber, R. H. \& Porter, C. C. (I950). In Protein and Amino Acid Requirements of Mammals, p. 75. [A. A. Albanese, editor.] New York: Academic Press.

Thomas, K. (1909). Arch. Anat. Physiol., Lpz,, Physiol. Abt. p. 2 rg.

Vardi, P. \& Tatar, I. (1954). Acta. physiol. hung. 6, 3 I 3.

Whipple, G. H. (1948). Haemoglobin, Plasma Protein and Cell Protein. Springfield, IH.: C. C. Thomas.

\section{Ghemical methods of evaluating protein quality}

\section{By K. J. Carpenter, School of Agriculture, University of Cambridge}

It has been shown experimentally that one protein may be superior to another in one set of circumstances, and yet in another set of circumstances be inferior. This difference arises, of course, from the requirement for protein being really a compound set of requirements for individual amino-acids (which are contributed in different proportions by different foods) and from the practical situation where 